\title{
Analysis of Online Marketing Management in Czech Republic
}

\author{
Zdenek Smutny
}

\begin{abstract}
Department of Systems Analysis, Faculty of Informatics and Statistics, University of Economics, Prague zdenek.smutny@vse.cz
\end{abstract}

\begin{abstract}
Background and Purpose: Doing business over the Internet has become increasingly competitive for many companies. The aim of this study is to analyse the current state of utilizing online tools, approaches of Czech companies to the management of online marketing activities and to identify weaknesses and opportunities of these activities.

Methodology/Approach: The paper presents empirical research that uses two different approaches in investigation: (1) descriptive quantitative research of current state, based on examination of websites of a sample of 4,584 Czech companies and (2) questionnaire survey among 161 Czech companies which do business via the Internet.

Results: There is a large gap that currently exist between the use of social media and its connection to marketing activities. The competitive level of the use of social media in the Czech Republic is still low compared to the USA companies. The online marketing management (OMM) of the majority of companies rely on individual assessment and do not use any metrics or management methodologies. One of the main problems of OMM is the ever increasing number of tools used in marketing activities as well as low possibility of a broader perspective on the success of cross channel marketing activities.

Conclusion: In the future, it is expected that a large number of Czech companies will increasingly use online tools as social media for their marketing activities. In the context of this development they cannot rely only on individual assessment to manage these activities as they do currently, but they will have to use comprehensive tools or methodologies. Based on this, we can conclude that Czech companies still have enough opportunities for a better use of online tools for marketing purposes.
\end{abstract}

Keywords: online marketing; management; analysis; social media; Czech companies; Internet

\section{Introduction}

The phenomenon of social media and their impact on human communication possibilities as well as commercial subjects is undeniable. A long-term trend in the field of applied research is the creation of methodologies and models which support management of marketing activities of commercial subjects on the Internet, where a crucial role is played by communication through social media - see for example (Wu and Wu, 2014; Dasilva et al., 2013; Krishnamurthy, 2006).

Social media also play an important role in other areas and approaches which are applied mainly to the market environment such as Competitive Intelligence (Molnar and Strelka, 2012), Marketing and Business Intelligence (Jasek and Vrana, 2014; Novotny and Jasek, 2013) or towards Information Management within a company (Doucek,
Pavlicek and Nedomova, 2011; Ungerman and Myslivcova, 2014).

In addition to the practically oriented approaches such as creating frameworks, models, methods or artefacts in general in order to solve defined issues, companies also need information about their surroundings. The information about the business environment in each country is available through global, European or national monitoring. For example, business activities in the Czech Republic are described in the Global Entrepreneurship Monitor (Lukes, Jakl and Zouhar, 2014). This article, based on a survey conducted among a sample of 607 entrepreneurs, shows subjective perception of business environment by individual commercial subjects. In the survey, respondents were asked to specify one or two major problems in their business activity. A total of $14.8 \%$ of the entrepreneurs answered that a major problem is a competitive environment.

Received: February 6, 2015; revised: March 20, 2015; accepted; April 25, 2015 
A total of $21.7 \%$ of the entrepreneurs said that they had lost clients and had few contracts, which is a very similar factor to the competitive environment. In connection with the competitive environment, the most frequently mentioned factors were oversaturated market, competitive pressure, and especially Internet competition. Besides these multinational monitoring reports, there are also specific articles focusing for example on the factors affecting entry into business (Lukes et al., 2013), impacts of ICT (Information and Communication Technologies) on the economy (Doucek, Fischer and Novotny, 2014) or impacts of ICT on labour productivity in the Czech Republic (Fischer et al., 2013). Creating some empirical base and understanding of related phenomena is essential (and a precursor) for the design of approaches to online management strategies (Klaus, 2013), which brings the issue back to the design of artefacts.

In the Czech environment we can find a number of comparative and case studies on various aspects of marketing activity - market segmentation and targeting potential customers (Stritesky and Stritesky, 2014), analysis of the availability of private data and behaviour of Facebook users (Cermak, Smutny and Janoscik, 2014), processing the data about customer activities (Jasek, 2014) or qualitative approaches to evaluation of marketing activities (Karlicek et al., 2014; Vojtko, 2014).

From the point of view of online marketing and its management, the penetration or use of social media in a particular segment in other companies is very important. This information is especially suitable on the level of strategic management, where decisions are made about instruments that will be used for marketing purposes in the longterm, and also to determine whether these instruments bring a (competitive) advantage over the competitors - see also (Dorcak and Delina, 2011), or whether it is already an established standard of communication in a given area.

After this broader overview of the competitive environment of the company, they approach to implementation, i.e. to the actual activities (the use of best practices, mediaplan preparation) and their evaluation. In the course of evaluating the goals, including positive and negative impacts of the interaction of subjects - see (Gecti and Dastan, 2013) - companies also compare their competitive position in the market segment. At this level, suitable sources of information for the management are externally provided statistics - e.g. companies Socialbakers (socialbakers. com) or Viralheat (viralheat.com).

The broader view outlined above has also been the motivation for this article: to analyse information about the use of social media and the way companies approach to online marketing management, with an emphasis on those that operate in the environment of services on the Internet. In addition to the presentation of our own research results, we will also use aggregate results from other surveys (Section 1.1) for basic comparison.

The purpose of this study is to provide a new insight

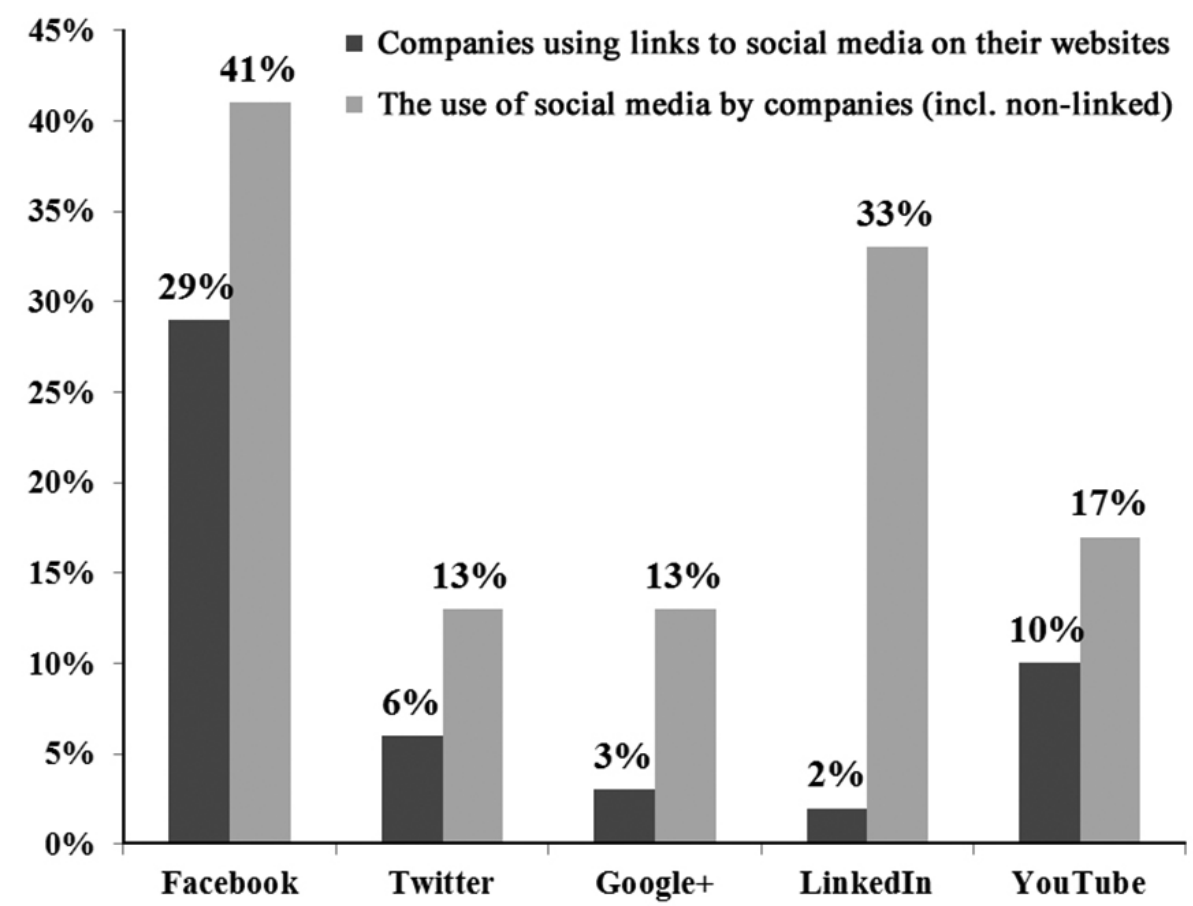

Figure 1: Aggregate results of surveys (Smutny et al., 2013; Filova, 2013) among companies in the "Czech Top 100" chart in 2012 comparing (the absence of) linking of websites and social media 
into the current situation related to the effective use of selected social media by commercial subjects in the Czech Republic. In addition, there can also be found similarly oriented and holistically focused studies, although thematically different - e.g. the use of social media by Indonesian SME (Sarosa, 2012), the use of social media for relationship management in Germany (Kruger et al., 2013), the use of Twitter by large U.S. companies (Culnan, McHugh and Zubillaga, 2010), and the use of social media in marketing in Pakistan (Khan and Bhatti, 2012).

\subsection{Previous investigations in Czech Re- public}

An examination of the currently available sources related to the Czech Republic reveals that they mostly look at social media as a means of communication. This is a view taken also in the study (Michl, 2013) conducted on 1,624 Czech accounts on Google Analytics. An important conclusion of this study is the rapid increase in website visits coming from social networks, which is gradually catching up with organic traffic from search engines. Conversely, there is a decrease in the number of visits from catalogues. The study also compares the increase in the number of Facebook and Twitter users in the Czech Republic and worldwide and discusses selected global trends related to the penetration of these two social networking sites into Czech society.

Another survey (Filova, 2013) deals with the use of five selected social media by commercial subjects listed in the "Czech Top 100" chart in 2012. These companies vary greatly in terms of the type of business and their overall size. The results of the survey presented in Figure 1 were complemented by a survey published in (Smutny et al., 2013), which was carried out on the same sample of companies, but the views taken in these surveys vary. While the first one deals with the existence of a company profile in social media, the second view focuses on the integration of social media into a company's website in compliance with the concept of integrated marketing communication. This means linking different tools and enabling visitors to switch between individual communication channels (tools), as well as distributing further specific content (audio, video, short messages, opinions).

This creates a synergic effect, i.e. a combined effect of several tools. Based on this, we can conclude that there is still a large percentage of companies that focus more on the use of social media as individual tools, rather than on the concept of creating integrated marketing communication via the Internet, with an emphasis on linking and supporting the interactions of subjects (people) in the internet-mediated environment.

\section{Methodology}

The article presents two-stage study. First of all, the websites of 4,584 companies doing business in field of interned-mediated services in the Czech Republic were examined and these companies were subsequently addressed and asked to participate in the questionnaire survey. We used the catalogues of companies listed on the portals of Seznam.cz and Centrum Holdings, which list predominantly small and medium enterprises (SME) or self-employed individuals. Companies which were considered in our survey were found in the following sections of the catalogue: e-shops (18\%), media agencies $(23 \%)$, on-line services $(31 \%)$, software companies $(20 \%)$, web developers $(8 \%)$. Data were collected by eighty students in their own project work during November and December 2013. The collected data were then cleared of redundancies.

Data were collected into Excel sheets and then aggregated and processed by the author for the purposes of this study. For every corporate website we examined whether there was a link (in the form of a direct URL link) between the company website and a selected social medium. As was shown by Smutny et al. (2013), in order to effectively communicate (or promote) in the environment of services on the Internet, a company should integrate social media into the company's website at least at the level of a link. For this reason, we did not check whether there existed company profiles on the individual social media if the link was not listed on the website. This leads to certain limitations of the gathered data; on the other hand, we obtained data of a different quality: such that represent the companies which have the potential to effectively communicate their message in the internet-mediated environment.

In addition, e-mail contacts were collected for the subsequent questionnaire survey (see Section 3.2). Its purpose was to obtain the views of these companies on the issue of marketing management. In total, 4,607 e-mail contacts (marketing or sales specialists) whose companies' websites had been previously examined were collected and questionnaires were sent to them.

The collection was carried out from September to December 2014. A total of 415 e-mails were undeliverable. From 4,192 delivered e-mails the response rate was 3.84\% $(n=161)$. It primarily included companies that have existed for five years or more (76\%). Responses from micro-size companies with up to 10 employees $(58 \%)$ and small companies with up to 50 employees $(28 \%)$ prevailed. The questionnaire was directed to marketing and sales specialists, who had university education (64\%) or secondary school education with school-leaving exam (27\%).

The majority of respondents were male $(76 \%)$ - they were the owners of companies $(69 \%)$ or regular employees, such as marketing or sales specialists (14\%). Considering the small number of companies in this investigation, the companies are not divided into individual areas, unlike 
the quantitative investigation described in Section 3.1.

\section{Results}

The first part (Section 3.1) identifies and describes the state of the use of online tools by Czech companies and their linking with the website. The results will be compared with similar studies carried out with other sets of companies (see Section 1.1). The differences will be highlighted, discussed and possible future development trends will be indicated (see Section 4).

The second part (Section 3.2) shows a view of marketing specialists on online marketing activities of the companies, using online tools (the previous analysis provided an external view, which this stage will complement with an internal view) and their approach to managing online marketing activities. The goal of these investigations is to provide an answer to the following three questions:

1. What percentage of Czech companies doing business via the Internet link their websites with their profiles on selected social media?

2. What tools do Czech marketing specialists consider to be important for marketing activities carried out over the Internet?

3. What issues do marketing specialists consider the most important in the managing of marketing activities in the Internet environment?

\subsection{Examination of companies' websites}

The basic results of websites examination rounded to whole numbers are presented in Table 1. The diagonal highlights information about the proportional use of social media within the total sample of 4,584 companies. This table also shows the percentage of combinations of two selected social media. For example, the figure (4\%) in column 23 , line 4 indicates that $4 \%$ of companies use
LinkedIn and Twitter.

The communications triad - the combination of social networking service, microblogging service and video hosting service (Facebook, Twitter, YouTube) - is used only by $3 \%$ of the companies. The available data also show that $62 \%$ of companies do not use any social media (apart from an e-mail or contact form) for communication over the Internet or they do not create a link between their website and the social media.

For a closer look the data were further divided into four segments (e-shops, media agencies, on-line services, software and web development companies) and submitted to the same analysis; the software companies groups and web developers were merged due to their proximity. The results are shown in Figures 2 and 3, with added average values of the four segments combined. This shows two distinctive counterparts.

The first are on-line services (in catalogues also referred to as Internet services) that consist on services provided over the Internet (e.g. insurance mediation, cloud services) and among them can also be found the representatives of the other three groups. Compared with the other groups, they had the best percentage results on Facebook, Twitter, YouTube, Blogs, Flickr, and Pinterest.

The second group are e-shops, which had the worst results in the using of social media in Twitter, YouTube, LinkedIn, Google+, Blogs, Flickr, and Pinterest. This e-shops behaviour may have been caused by the fact that many small e-shops do not have the human resources to maintain a larger network concerning social media, and therefore focus mainly on Facebook and advertising activities via search engines.

It is interesting that software and web development companies have the best results with the professional social network LinkedIn, positive balance is also remarkable in the penetration of the relatively new social network Google+. Although it is not significantly different from On-line

Table 1: The diagonal of the table shows the use of selected social media of Czech companies. Furthermore, a percentage of the total companies' number, which use two selected social media, can be seen here.

\begin{tabular}{|c|c|c|c|c|c|c|c|c|}
\cline { 2 - 9 } \multicolumn{1}{c|}{} & Facebook & Twitter & Google+ & LinkedIn & YouTube & Blogs & Flickr & Pinterest1 \\
\hline Facebook & $\mathbf{2 8 \%}$ & - & - & - & - & - & - & - \\
\hline Twitter & $11 \%$ & $\mathbf{1 2 \%}$ & - & - & - & - & - & - \\
\hline Google+ & $8 \%$ & $5 \%$ & $\mathbf{1 1 \%}$ & - & - & - & - & - \\
\hline LinkedIn & $6 \%$ & $4 \%$ & $3 \%$ & $\mathbf{8 \%}$ & - & - & - & - \\
\hline YouTube & $6 \%$ & $3 \%$ & $3 \%$ & $3 \%$ & $\mathbf{7 \%}$ & - & - & - \\
\hline Blogs & $2 \%$ & $2 \%$ & $1 \%$ & $1 \%$ & $1 \%$ & $\mathbf{4 \%}$ & - & - \\
\hline Flickr & $1 \%$ & $<1 \%$ & $1 \%$ & $1 \%$ & $1 \%$ & $<1 \%$ & $\mathbf{1 \%}$ & - \\
\hline Pinterest & $1 \%$ & $<1 \%$ & $<1 \%$ & $<1 \%$ & $<1 \%$ & $<1 \%$ & $<1 \%$ & $\mathbf{1 \%}$ \\
\hline
\end{tabular}

1 Pinterest is an internet-based service that enables users to create free thematic collection of pictures or photos (see pinterest. com). 
services, if we compare it with the other two groups, we can say that it emphasizes the role of virtual life, whether it is on a professional or a personal level, in the social group of ICT experts. This is also reflected in the increased motivation of commercial subjects residing in the same virtual environments as their staff.

Besides the results concerning selected social media, we also investigated other kinds of communication popular with the general public. Their functions have been gradually integrated primarily into social networking, namely Voice over Internet Protocol (VoIP) and Instant Messaging (IM) clients, whose representatives are Skype and ICQ. Both remain in our study above $4 \%$ of the total number of companies. In terms of individual segments, IM is used mostly by e-shops and VoIP by software and web companies. In contrast, there is the lowest use of IM and VoIP in media agencies. The current survey focusing on the use of these and other tools for internal communication was presented in (Zerfass et al., 2014).

\subsection{Results of the questionnaire survey}

The results of questionnaire survey presented in this section focus on the subjective view of individual companies

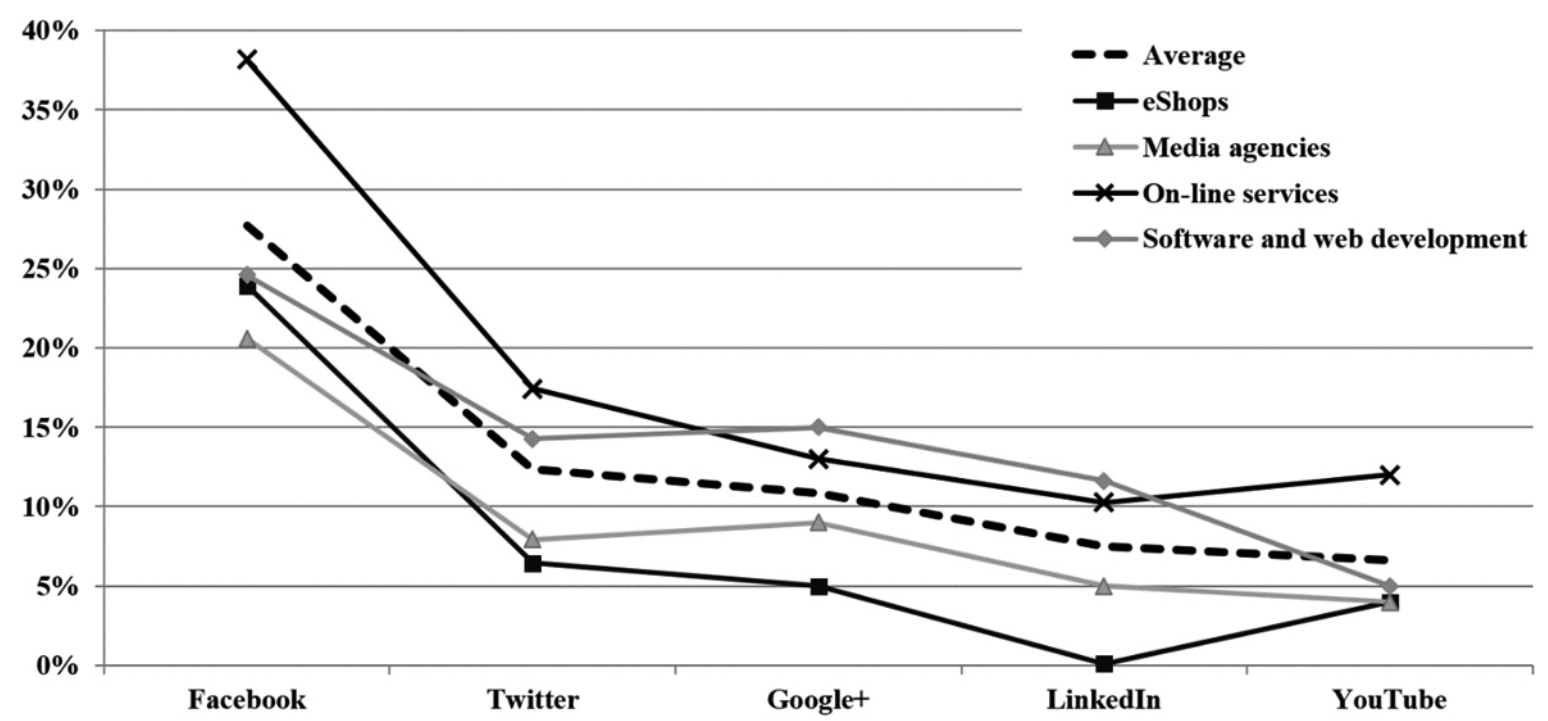

Figure 2: Percentage distribution of each social media in the four selected segments (sample of 4584 companies).

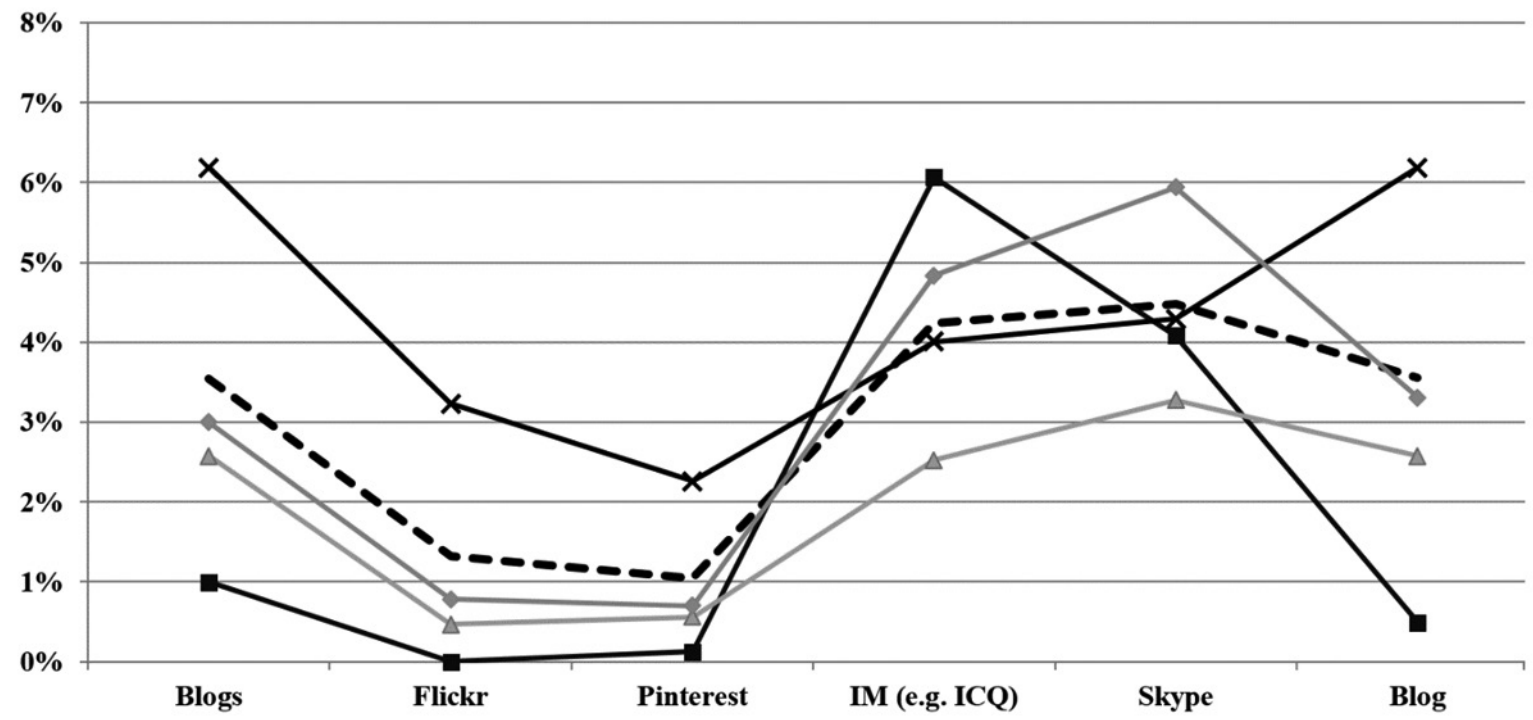

Figure 3: Percentage distribution of other online tools in the four selected segments, as shown in Figure 2 (sample of 4584 companies). 
(their marketing specialists) concerning their marketing activities, opinions on current approaches to online marketing management and the difficulties faced. The accent was put on their approaches to the management of marketing activities via the Internet (data collection, evaluation and interpretation, strategic decisions). Questions and options for answers contained in the questionnaire are presented in Appendix.

First, it should be mentioned that for $81 \%$ of respondents from the sample of companies, online environment is important in order to make a profit (see Question 4). Approximately half (49\%) of respondents indicated that they connect marketing campaigns involving the physical environment with those in the online environment. The same percentage stated that they do not connect campaigns in these environments and $2 \%$ of respondents did not know (see Question 10 in Appendix).

Section 3.1 examines individual tools; Table 2, in contrast, summarizes the use of groups of tools. We focused not only on communication, but also on the distribution tools. From the viewpoint of the importance of marketing activities, organization websites dominates followed by social networks. Discussion forums were in the third place, which is an interesting result. They often shape a company, product or service and they are a critical success factor in the social dimension of the marketing campaign. People can recommend or advise about products and services available on the market - Word of Mouth. These opinions can also be automatically processed, analysed and compared with the competition - see (Sperkova, 2014). Discussion forums are important for companies because from them they get opinions on their products or services, but also information about the needs of their customers - Voice of Customers - which thus improves their understanding of customers' needs and enables their transformation into product or service features.

From Questions 1 and 2 (see Appendix) can be determined the greatest differences between what marketing specialists considered an important tool for marketing activities (see Table 2) and the tools that were really used by their companies. The biggest differences were found among the discussion forums (difference 29\%), web blogs (difference 21\%), online videos and pictures (e.g. YouTube, Pinterest; difference 22\%) listed in the questionnaire, where the perceived importance of the tools was higher than current use of those tools by companies.

The following part will focus only on communication tools, which are often used for online promotional mix. Types or methods of online marketing communication are shown in Figure 3 (see also Question 9 in Appendix). In online marketing communication, companies put the greatest emphasis on their website and associated search engine optimization, which generates organic website traffic.

For direct communication with customers (see Question 5 and 6 in Appendix), only 24\% of respondents consider social networks important. Tools intended strictly for direct communication (e.g. technical support), such as IM and VoIP, are considered important only by $20 \%$ of respondents.

Table 2: According to their professional opinion, employees of individual companies reported the level of importance of the suggested instruments for marketing activities carried out via the Internet. The scale of 1 (totally unimportant) - 5 (very important), $n=161$. The column "Importance" shows the percentage of those who respond positively (they indicated 4 or 5 on the scale).

\begin{tabular}{|c|c|c|c|}
\hline Marketing tools & Importance & Average & Deviation \\
\hline Organization website & $96 \%$ & 4.69 & 0.73 \\
\hline Social networks (Facebook, Google+) & $79 \%$ & 3.89 & 1.05 \\
\hline Discussion forums & $58 \%$ & 3.41 & 1.02 \\
\hline $\begin{array}{c}\text { Online video and pictures } \\
\text { (YouTube, Pinterest) }\end{array}$ & $57 \%$ & 3.41 & 1.05 \\
\hline Web blogs & $55 \%$ & 3.38 & 1.09 \\
\hline Microblogs (Twitter) & $42 \%$ & 3.06 & 1.06 \\
\hline $\begin{array}{c}\text { Virtual marketplaces } \\
\text { (AppStore, Google Play) }\end{array}$ & $26 \%$ & 2.82 & 0.92 \\
\hline Online audio & $10 \%$ & 2.42 & \\
\hline
\end{tabular}




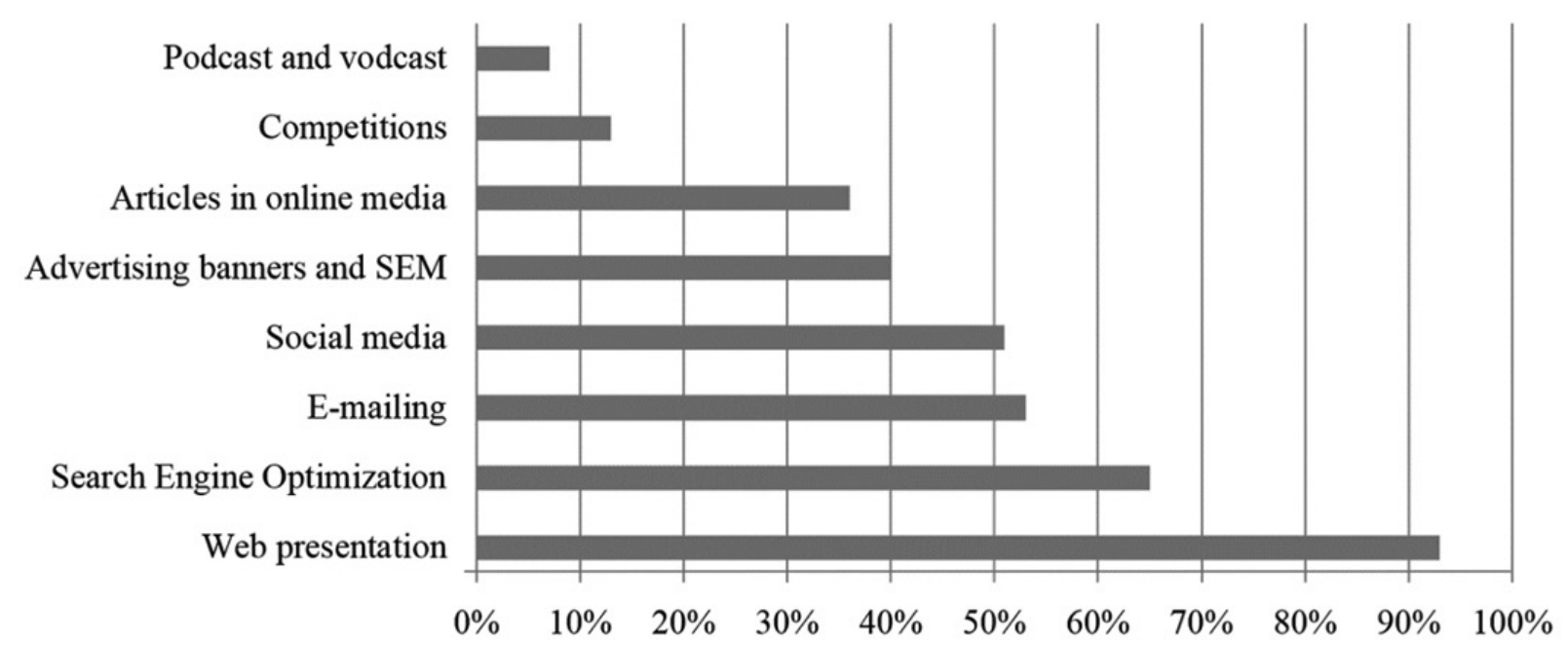

Figure 4: Types or methods of online marketing communication on which Czech companies put emphasis (sample of 161 companies).

Let us now focus on questions from the questionnaire survey related to the management of online marketing activities, which begins with the evaluation of obtained data and how professionals are able to make decisions based on this about subsequent activities. Question 7 (see Appendix), examined how the companies do the evaluation of marketing activities and subsequent decisions affecting future marketing activities. Half of the companies (53\%) are fully dependent only on a subjective evaluation of the obtained data. The effectiveness of marketing management is to a large extent influenced not only by professional knowledge of workers, but especially by his or her limits (in the case of complex campaigns it is the limit of insight, which is given by human cognitive capabilities).

Metrics is used by $37 \%$ of companies and more advanced tools for evaluation are used only by $10 \%$. This may be due to the fact that most of the companies which participated in the survey belong to the category of micro- and small business. Based on this information, we can identify areas that would improve the capabilities of organizations in online marketing management - establish a balance between instrumental and systematic education of marketing professionals and the availability of simple (free) programs or methodologies for evaluating marketing activities. A solution for the second area is a currently developed methodology for continuous evaluation of online marketing activities specified in (Smutny and Vojir, 2015).

If we focus only on the communication activities in the online environment, $78 \%$ of companies ensure their propagation by their own resources. In contrast, only $2 \%$ of companies use services of an external organization that provides full-service marketing communication and $19 \%$ of companies use services of external organizations partially. In terms of management of these activities it is significant that $40 \%$ of the companies use staff or departments for these purposes which have other working agenda (see Question 8 in Appendix). This may have an impact on decision-making, because workers do not have to pay adequate attention to this agenda (management). The two biggest problems that companies have in the management of marketing activities in the online environment (see Question 3 in Appendix) are as follows:

1. Increasing time demands associated with the use of a large number of tools and services (e.g. social media, advertising systems).

2. The inability to create a holistic view of the success of their marketing activities. Currently, they rely only on partial instruments providing individual statistics.

According to the questionnaire survey, $73 \%$ of the companies surveyed agree with these statements. In the case of other options the level of agreement was lower.

\section{Discussion}

The presented examination of companies' websites (Section 3.1) provides different perspectives emphasizing the integrity of marketing communication and therefore also the linking of a company's website to social media and thus their basic integration at least. Websites are the primary reflection of a company in virtual environment - see (Smutny et al., 2013), and therefore it is the central point around which the interaction of the subjects of the environment (in our view mainly people) revolves.

The presented study reflects that and deals with only social media that is linked with websites. Based on the obtained data, it was found that $62 \%$ of Czech companies do 
not link their websites with their profiles on selected social media. Because this was an exploratory research of the current state, its main outcome is the description of data in Table 1, Figure 1 and 2.

From an international perspective, it would be interesting to compare the results shown in Table 1 with some similar earlier studies concerning companies from other countries and discuss the differences. In 2013, an identical study was carried out (Smutny et al., 2013) on a smaller sample of companies within the "Czech Top 100" chart in the Czech Republic and the "Fortune 500" chart in the USA (although the types of business were different).

A comparison of the results of our investigation and the "Czech Top 100" shows that in the case of the Czech Republic a similar result of Facebook's integration concerning websites (29\% in "Czech Top 100 " versus $28 \%$ in Table 1). In other social media that have been monitored the differences are greater, which is mainly due to the greater differences between the specialization of the individual companies (e.g. B2B, B2C, B2G). There can also be expected a greater use of social media and linking with websites by companies doing business via the Internet (presented in Section 3.1). This was indicated by the comparison.

Compared to the USA, we can find bigger differences, which determine the direction and the gap that Czech companies will probably try to fill in the field of communication regardless of the business. In the case of the USA, Facebook is stated in the websites of $74 \%$ of companies. In other monitored social media, the difference was more than tenfold in favour of US companies. This implies that the competition between Czech companies in terms of using social media for active promotion is still low compared to USA's. Therefore, marketing activities through social media have still in the Czech context a competitive advantage considering their greater penetration and use in Czech society in general - see (Michl, 2013).

In the opinion of respondents the most important tools ${ }^{2}$ for online marketing activities are (see Table 2): organization website, social networks, discussion forums, online video and pictures, and web blogs. When comparing what marketing specialists consider as important online tools and what is really used in companies, the major differences were between the discussion forums, web blogs and online videos and pictures (e.g. YouTube, Pinterest) listed in the questionnaire. The main reasons for these differences in author's opinion may be as follows:

- Time demands for creating and maintaining official or unofficial content (e.g. periodical blog writing).

- Risk of confrontation because of anonymity (for example) on discussion forums. Mismanagement of conversation can have very negative effects which are searchable for a long time - see also (Mesicek, 2014).

- Bigger time demands on staff (as well as financial de- mands on the company) because of the need for continual control of content and solving positive and negative feedback.

- The technical difficulty of creating multimedia or visual materials for internet-based services such as YouTube or Pinterest. These include the ability of workers to record and process videos and the need to respect copyright on adopted parts.

- Lower chance of an analytical evaluation of the direct impact of these PR activities on company's business. Therefore marketing specialists rather prefer services providing hard data related to the success of the campaign.

Two problems which are interconnected were pointed out as the biggest problem by the same number of respondents. The first is the increasing number of tools used for online marketing activities, which also means increasing time demands for managing these activities. The second problem which the companies face is the inability to create a holistic view of the success of marketing activities.

At the same time the survey pointed out that $40 \%$ of companies use their own staff to manage marketing activities. However, these employees have also a different working agenda. The time demand associated with managing many tools and services including additional work agenda may have a negative impact on the management of online marketing activities. Due to the number of used tools, an integrative view is missing, which would provide a wider systems perspective on the activities and generated feedback. The most important article results can be summarized as follows:

- Based on the comparison of investigations surveys (Filova, 2013) and (Smutny et al., 2013), there can be seen a large gap between the use of social media (profile creation and management) and its active connection within integrated marketing communication towards creating synergistic effects at the level of subjects interaction in the environment. When compared to the state of companies in the USA, the competition level on the use of social media in the Czech Republic is lower.

- The presented survey based on a sample of 4,584 companies doing business in the environment of services on the Internet reflects the low level of competition in the context of effective integrated communication in this area. Here we highlight just some general conclusions:

- $62 \%$ of companies in the Czech Republic do not use for communication via Internet any social media or they do not create a link between their website and the social media, which makes it look as if they did not have any social media profile.

- Means for rapid communication (VoIP and IM)

2 More than $50 \%$ of respondents think that they are important; they are marked 4 or 5 on the scale 1 to 5 . 
are employed to the greatest extent by e-shops and software and web companies, but their penetration is generally low.

- In the questionnaire survey the main problems that affect online marketing management were identified.

- The majority of Czech companies (53\%) does not use metrics or other approaches (methodologies, software) and uses only the expert knowledge of marketing professionals (individual assessment). There is room for improvement and innovation in terms of the development of easily applicable methodologies or aggregation software.

- Among the major problems perceived by companies are: (a) the increasing time needed for using more and more tools for marketing activities and thus for their management; (b) low ability to create a holistic view of the success of the marketing activities.

This difference in approach to assessment of marketing activities can be caused by a lack of competent experts in the field of social media towards their use in the commercial sector. This negative aspect is discernible already at the level of management and strategic planning and it spreads further to the organization of activities, which is shown also in the research of Altimeter Company (Solis and Li, 2013), which, however, was carried out in the USA.

\section{Conclusion}

The study presented a different approach, focusing not on the individual social media and the statistics describing their usage by humans or commercial subjects, as mentioned in (Michl, 2013). On the contrary, the survey is conducted on a selected group of companies doing business via the Internet and focuses on the linking of social media and websites. We think that a more suitable approach, as it reflects the real situation of the use of online tools in the segment. It provides much-needed information on the status of social media in a given segment, which aptly complements the information about competitive environment. The study also emphasized the main issues faced by the sample of Czech companies.

These results are interesting for companies when choosing an (initial) mix of social media. A company can choose which the tools they use and which are therefore relevant to their area of business. Although the social media are an important phenomenon of our time, this situation is not fully reflected at the level of companies operating in online environment (compared to the USA). For this reason, the effective involvement of this form of communication in an integrated marketing campaign for Czech companies still means a significant competitive advantage. The presented two-stage study has also the following limitations. Although in the questionnaire survey were addressed the same organizations whose websites were examined in Section 3.1, the conclusions of the survey cannot be directly applied to the initial sample of 4,584 organizations.

The reason for this is a low response rate and a different composition of respondents. Although the sample of 4,584 organizations could be described as representative, characterizing it as a designation sample seems preferable, as it is difficult to determine the number of organizations in the Czech Republic doing business in the environment of services on the Internet, including a clear definition of which organizations fall within this area and which do not. We suggest to repeat this survey on a similar sample of companies to monitor the development in the approach of Czech companies not only to the use of online marketing tools, but also their approach to manage online marketing activities. However, another comparison is being prepared which focuses on the use of specific social media by companies in Central Europe. Based on this comparison, we will be able to analyse the differences in marketing approaches in different countries.

\section{Acknowledgements}

This article was prepared with the financial support of the research project VSE IGS F4/18/2014 (University of Economics, Prague), which is called Innovative view of customer value and other factors influencing marketing management.

\section{Literature}

Cermak, R., Smutny, Z., \& Janoscik, V. (2014). Analysis of the Facebook Privacy Settings of Young People with an Emphasis on the Czech Republic and France. In A. Rospigliosi \& S. Greener (Eds.), European Conference on Social Media, (pp. 613-621). Reading: ACPI.

Culnan, M.J., McHugh, P.J., \& Zubillaga, J.I. (2010). How large U.S. companies can use Twitter and other social media to gain business value. MIS Quarterly Executive, 9(4), 243-259.

Dasilva, J.P., Arratibel, A.G., Aierdi, K.M., Galdospín, T.M., Castillo, I.M., Mardaras, L.I., González, M.M., \& Santamarina, D.R. (2013). Companies on Facebook and Twitter. Current situation and communication strategies. Revista Latina de Comunicación Social, 68, 676-695, http://dx.doi.org/10.4185/RLCS-2013-996en

Dorcak, P., \& Delina, R. (2011). Impact of E-marketing Services on Economic Performance. Ekonomicky casopis, 59(1), 44-58.

Doucek, P., Fischer, J., \& Novotny, O. (2014). ICT and Economy. In P. Doucek, G. Chroust \& V. Oskrdal (Eds.), 22nd Interdisciplinary Information Management Talks, (pp. 55-62). Linz: Trauner.

Doucek, P., Pavlicek, A., \& Nedomova, L. (2011). Infor- 
mation Management in Web 2.0 Technology Context. In R. Nemec \& F. Zapletal (Eds.), Strategic Management and its Support by Information Systems, (pp. 3445). Ostrava: VSB TU Ostrava.

Filova, J. (2013). Top sociální média v českých firmách [Top social media used in Czech companies]. Retrieved November 29, 2014, from http://janafilova. wordpress.com/2013/08/13/top-socialni-media-v-ceskych-firmach/

Fischer, J., Vltavska, K., Doucek, P., \& Hanclova, J. (2013). Vliv informačních a komunikačních technologií na produktivitu práce a souhrnnou produktivitu faktorů v České republice [The Influence of Information and Communication Technologies on Labour Productivity and Total Factor Productivity in the Czech Republic]. Politická ekonomie, 61(5), 653-674.

Gecti, F., \& Dastan, I. (2013). The Impact of Social Media-Focused Information \& Communication Technologies on Business Performance via Mediating Mechanisms: An Exploratory Study on Communication and Advertising Agencies in Turkey. International Journal of Business and Management, 8(7), 106-115, http://dx. doi.org/10.5539/ijbm.v8n7p106

Jasek, P. (2014). Analyzing user activity based on RFM models complemented with website visits and social network interactions. In P. Doucek, G. Chroust \& V. Oskrdal (Eds.), 22nd Interdisciplinary Information Management Talks, (pp. 145-152). Linz: Trauner.

Jasek, P., \& Vrana, L. (2014). Managerial Impacts of Different Computation Models for Customer Lifetime Value for an E-commerce Company. In T. Loster \& T. Pavelka (Eds.), 8th International Days of Statistics and Economics, (pp. 678-686). Slany: Melandrium.

Karlicek, M., Chytkova, Z., Tyll, L., \& Mohelska, H. (2014). Barriers of Marketing Effectiveness and Efficiency within Companies: A Qualitative Study. $E+M$. Ekonomie a Management, 17(4), 111-124, http://dx. doi.org/10.15240/tul/001/2014-4-009

Khan, S.A., \& Bhatti, R. (2012). Application of social media in marketing of library and information services: A case study from Pakistan. Webology, 9(1).

Klaus, P. (2013). New insights from practice: Exploring online channel management strategies and the use of social media as a market research tool. International Journal of Market Research, 55(6), 829-850, http://dx. doi.org/10.2501/IJMR-2013-069

Krishnamurthy, S. (2006). Introducing E-MARKPLAN: A practical methodology to plan e-marketing activities. Business Horizons, 49, 51-60.

Kruger, N., Dang-Xuan, L., Schneider, A.-M., \& Stieglitz, S. (2013). Usage of social media for external stakeholder relationship management - a study of German companies and international non-government organizations. In L. Barolli, F. Xhafa, M. Takizawa, T. Enoki- do \& H-H. Hsu (Eds.), 27th International Conference on Advanced Information Networking and Applications Workshops, (pp. 1479-1482). Los Alamitos: CPS. Lukes, M., Jakl, M., \& Zouhar, J. (2014). Global Entrepreneurship Monitor 2013: Podnikatelská aktivita v České republice [Entrepreneurial activity in the Czech Republic]. Prague: Global Entrepreneurship Research Association.

Lukes, M., Zouhar, J., Jakl, M., \& Ocko, P. (2013). Faktory ovlivňující vstup do podnikání: začínající podnikatelé v České republice [Factors Influencing Entrepreneurial Entry: Early-stage Entrepreneurs in the Czech Republic]. Politická ekonomie, 61(2), 229-247.

Michl, P. (2013). Infografika: Sociální sitě v Česku [Infographics: Social Networking in the Czech Republic]. Retrieved November 29, 2014, from http:// www.m-journal.cz/cs/internet/socialni-site/infografika--socialni-site-v-cesku_s416x9788.html

Molnar, Z., \& Strelka, J. (2012). Competitive Intelligence for small and middle enterprises. E+M. Ekonomie a Management, 15(3), 156-170.

Novotny, O., \& Jasek, P. (2013). Enhancing Customer Lifetime Value with Perceptual Measures Contained in Enterprise Information Systems. In J. Basl, P. Jasek, O. Novotny \& A. M. Tjoa (Eds.), 7th International Conference on Research and Practical Issues of Enterprise Information Systems, (pp. 211-220). Linz: Trauner.

Sarosa, S. (2012). Adoption of social media networks by Indonesian SME: A case study. Procedia Economics and Finance, 4, 244-254, http://dx.doi.org/10.1016/ $\underline{\mathrm{S} 2212-5671(12) 00339-5}$

Smutny, Z., \& Vojir, S. (2015). A Methodology Concept of Online Marketing Management with a Knowledge Base of Interactions from Internet-based Services. In D. Ramjugernath (ed.), 3rd International Conference on Innovation and Entrepreneurship, (pp. 242-249). Reading: ACPI.

Smutny, Z., Reznicek, V., Kalina, J., \& Galba, A. (2013). Interaction of Social Media and Its Use in Marketing Management. In P. Doucek, G. Chroust \& V. Oskrdal (Eds.), 21st Interdisciplinary Information Management Talks, (pp. 167-174). Linz: Trauner.

Solis, B., \& Li, C. (2013). The State of Social Business 2013: The Maturing of Social Media into Social Business. Retrieved November 21, 2014, from http://www. altimetergroup.com/research/reports/the state_of_social business 2013

Sperkova, L. (2014). Analýza nestrukturovaných dat z bankovních stránek na sociální síti Facebook [Unstructured Data Analysis from Facebook Banking Sites]. Acta Informatica Pragensia, 3(2), 154-167.

Stritesky, V., \& Stritesky, M. (2014). Demografické cílení internetové reklamy [Demographic Targeting of Internet Advertising]. Acta Informatica Pragensia, 3(2), 
137-153.

Ungerman, O., \& Myslivcova S. (2014). Model of communication useable for small and medium-sized companies for the consumer communication in social media. E+M. Ekonomie a Management, 17(1), 167-184, http://dx.doi.org/10.15240/tul/001/2014-1-013

Vojtko, V. (2014). Rethinking the Concept of Just Noticeable Difference in Online Marketing. Acta Informatica Pragensia, 3(2), 204-219.

Wu, I-L., \& Wu, S-M. (2015). A strategy-based model for implementing channel integration in e-commerce. Internet Research, 25(2), 239-261, http://dx.doi. org/10.1108/IntR-10-2013-0212

Zerfass, A. et al. (2014). European Communication Monitor 2014. Brussels: EACD/EUPRERA, Helios Media.
Zdenek Smutny is teaching assistant at the Department of Systems Analysis, University of Economics, Prague and also project manager at Telematix Group. He graduated in applied informatics and media studies. He deals with a wide concept of social informatics: interaction between ICT and humans at the organizational (micro) and society (macro) level and ICT applications in the social sciences. 


\section{APPENDIX}

Listed below are only the core questions relevant to the topic of online marketing activities and their management (results presented in Section 3.2). The questionnaire also included questions about respondents and the companies in which they work. Summarised demographic data about respondents are listed in Section 2.

In questions 1 through 6, respondents rated the importance of or their (dis)agreement with the issues specified in the questions on a scale of 1 to 5, where 1 meant "not important at all", "not at all" or "definitively disagree", while 5 meant "greatly important", "to a great extent" or "definitively agree". Questions 7, 8 and 10 were multiple choice questions. Question 9 had a checkbox layout, where respondents could check more options.

Question 1: In your professional opinion, how important are the following tools for marketing activities carried out over the Internet:

Rated tools: Organization website, Social networks (e.g. Facebook, Google+), Discussion forums, Online video and pictures (e.g. YouTube, Pinterest), Web blogs, Microblogs (e.g. Twitter), Virtual marketplaces (e.g. AppStore, Google Play), Online audio

Question 2: How much does your organization use those tools for marketing activities carried out over the Internet? Rated tools: Organization website, Social networks (e.g. Facebook, Google+), Discussion forums, Online video and pictures (e.g. YouTube, Pinterest), Web blogs, Microblogs (e.g. Twitter), Virtual marketplaces (e.g. AppStore, Google Play), Online audio

Question 3: Which of the following do you view as problems in managing marketing activities on the Internet?

1: Increasing time demands associated with the use of a large number of tools and services (e.g. social media, advertising systems).

2: Rapid development of trends and thus the need for fast adjustment and use of still new tools.

3: Low number of true specialists with the necessary knowledge of and experience with online marketing activities.

4: The inability to create a holistic view of the success of their marketing activities, only a view of partial instruments providing individual statistics.

Question 4: How important is the online environment for your company's business (making profit)?

Question 5: How important are the social media (e.g. Facebook, Twitter) for you organization's communication with customers?

Question 6: How important for your organization's communication with customers are the specialized services VoIP and Instant Messaging (e.g. Skype, ICQ)?

Question 7: How do you evaluate marketing activities and subsequent decisions affecting future marketing activities?

1: An expert decides on the basis of available data and his or her previous experience (individual assessment).

2: An expert evaluates previously defined metrics and he or she decides only on their basis.

3: Expert decisions are partly based on previously defined metrics and partly on the basis of individual expert assessment of available data.

4: We use a sophisticated methodology for data evaluation, or its application variant (specialized software) and an expert decides on the basis of its results.

Question 8: Who in your organization is responsible for marketing communication (propagation) on the Internet?

1: Everything is done by an external organization.

2: It is partly done by an external organization(s) and partly by our own sources.

3: Everything is done by our specialized department or employee (marketing specialist).

4: Everything is done by a department or specialist who covers also other activities (agenda).

5: Ad hoc chosen employee or employees.

6: I do not know. 
Question 9: On which of the following types of online marketing communication does your organization put emphasis?

1: E-mailing

2: Web presentation

3: Social media

4: Articles in online media

5: Podcast and vodcast

6: Competitions

7: Search Engine Optimization

8: Advertising banners and SEM

Question 10: Does your organization link marketing campaigns in the physical environment (e.g. newspaper advertisements) with those on the Internet?

1: Yes

2: No

3: I do not know. 